\title{
Science Mapping of the Knowledge Base on Sustainable Entrepreneurship, 1996-2019
}

\section{Trin Thananusak}

Center for Research on Sustainable Leadership, College of Management, Mahidol University, 69 Vipavadee Rangsit Rd., Bangkok 10400, Thailand; trin.tha@mahidol.ac.th

Received: 16 June 2019; Accepted: 25 June 2019; Published: 28 June 2019

\begin{abstract}
After the launch of the United Nations' Brundtland's report in 1987, entrepreneurship has been promoted as one of the tools for achieving sustainable development. Since then, the studies in sustainable entrepreneurship have flourished and this topic has emerged as a subfield of entrepreneurship research. In order to examine the current stage of sustainable entrepreneurship (SE) research, this review utilized science mapping tools to analyze 712 Scopus-indexed documents written on the topic of sustainable entrepreneurship. This review assesses the size, publication evolution, and worldwide dispersion of research publications of this knowledge base as well as topics that have gained increased interest over the past few years. The review documented an emerging knowledge base, concentrated in Western developed societies. Sustainable entrepreneurship has evolved from earlier incarnations such as ecopreneurship and social entrepreneurship. Author co-citation analysis, three Schools of Thoughts (or three sub-themes) were identified in this knowledge base, namely Sustainable Entrepreneurship, Social Entrepreneurship, and Sustainability Innovation. This review aspires to provide a baseline bibliometric analysis of sustainable entrepreneurship research that both charts the evolution of this knowledge base and points towards productive lines of future inquiry.
\end{abstract}

Keywords: sustainable entrepreneurship; sustainability; ecopreneurship; social entrepreneurship; sustainability innovation; science mapping; bibliometric review

\section{Introduction}

Scholars have examined entrepreneurship and its crucial role in economic development for several decades [1,2]. According to Schumpeter [1], economic progress results from "creative destruction" caused by the recombination of resources of entrepreneurs. In other words, entrepreneurs function as an engine for wealth creation by discovering, creating, and exploiting opportunities and bringing products and services to markets $[3,4]$.

However, over the past few decades, imbalanced economic development has tended to favor short-term economic gain and maximization of profits. Unanticipated effects of this approach include social and environmental problems such as inequality, poverty, depletion of natural resources, degraded environment, and pollution. As a result, the United Nations, governments, and business communities have increasingly banded together in support of sustainable development initiatives [5].

This trend has also encompassed entrepreneurship. Entrepreneurs are regarded not only as drivers for economic growth, but also as front-line actors capable of reducing economic, social, and environmental problems in society. In this paper, the process of discovering, creating, exploiting opportunities to achieve 'triple bottom line' [6] or creating benefits for society, the planet, and profit, is termed "sustainable entrepreneurship" [7].

Although some scholars have begun to conduct reviews of the sustainable entrepreneurship (SE) literature [8-14], only a few studies [13,14] have systematically analyzed the full knowledge corpus 
of the field. Thus, this systematic review of research aims to analyze scholarly work published on sustainable entrepreneurship over the past two decades. The review addresses four research questions.

RQ1: What are the size, publication evolution, and worldwide dispersion of research publications on sustainable entrepreneurship?

RQ2: What sources, scholars, and research papers have been most influential in research on sustainable entrepreneurship?

RQ3: What is the intellectual structure of the sustainable entrepreneurship knowledge corpus?

RQ4: What subjects in the sustainable entrepreneurship literature have been researched most frequently?

The review addressed these questions using a science mapping approach to synthesize 712 research papers published between 1996 and early 2019. Bibliographic linked to these studies were analyzed using VOSviewer software to map the SE knowledge base [15-17]. This review of research differs from prior reviews of the social and sustainable entrepreneurship literatures [8-14] in two aspects. First, this study aimed to create a comprehensive review of the sustainable entrepreneurship knowledge base rather than focusing on a subset of documents. Thus, the use of science mapping methodology allowed the author to analyze a larger dataset than typical reviews that use critical synthesis, narrative synthesis, or meta-analysis. Second, rather than seeking to synthesize the "substantive findings" of studies, science mapping reviews aim to identify structural and relational trends that shape knowledge production in a given discipline $[15,16]$.

\section{Conceptual Background of the Review}

\section{Conceptualizing Sustainable Entrepreneurship (SE)}

This section traced the evolution of the SE concept and its earlier incarnation concepts such as ecopreneurship and social entrepreneurship in the context of entrepreneurship literature.

Entrepreneurship has been a growth engine in business and social sectors [17]. According to Sahlman [18], entrepreneurship is comprised of four interdependent components: people, context, deal, and opportunities, and entrepreneurs must create a fit among the four components. The goals of entrepreneurs are to create a personal, economic, and shareholder value by spotting opportunities in their contexts and mobilizing resources (people and capital) to provide products or services that address demands [17]. Thus, entrepreneurship scholars aim to 'understand how opportunities to bring into existence 'future' goods and services are discovered, created, and exploited, by whom, and with what consequences' [4] (p. 120).

In the 1990s, entrepreneurship literature began to expand its scope and scholars took a broader view of entrepreneurship research by linking entrepreneurial processes with social contexts (e.g., environmental and social problems) [2]. Hence, the interest in the intersection between entrepreneurship and sustainability arose. Scholars put forward the concept of ecopreneurship (or green entrepreneurship and environmental entrepreneurship) [19-21] to explain the phenomenon where entrepreneurs tried to use their entrepreneurial skills to set up ventures and address environmental problems. Ecopreneurs are environmentally oriented individuals who aspire to create economic value by solving environmental issues. For instance, Patagonia is an American company that produces environmentally friendly outfits and gear for outdoor activities. This company was set up in 1973 and has been 'in business to save our home planet' by trying to 'cause no unnecessary harm' to environments. It gives one percent of total sales revenue to environmental organisations, and its "worn wear" campaign encourages customers to buy used and repaired products [22].

Apart from ecopreneurship, in the late 1990s, scholars began to study a new strand of entrepreneurship whose mission was to address social problems (e.g., poverty and inequality). This process of social value creation is termed "social entrepreneurship" - a process that uses innovative solutions to create social value and address social problems and catalyzes social change $[17,23,24]$. The social value is the first priority of social entrepreneurs, whilst the economic value is necessary for creating organizational viability. Mair and Marti [23] defined social entrepreneurship as 'a process involving the innovative use and combination of 
resources to pursue opportunities to catalyze social change and/or address social needs' (p. 37). Similar to Mair and Marti's definition, Zahra et al. [24] defined social entrepreneurship as 'activities or processes undertaken to discover, define, and exploit opportunities in order to enhance social wealth by creating new ventures or managing existing organizations in an innovative manner' (p. 519). For instance, Muhammad Yunus set up Grameen bank to alleviate a poverty problem in Bangladesh. The bank lends money to poor women in the rural areas without collateral so that they can have capital to start a business and earn money from their microenterprises [25].

In the late 2000s, scholars began to examine another type of entrepreneurial process-sustainable entrepreneurship. Schaltegger and Wagner [26] defined sustainable entrepreneurship as 'an innovative, market-oriented and personality driven form of creating economic and societal value by means of break-through environmentally or socially beneficial markets or institutional innovations'(p. 226). They argued that both ecopreneurship and social entrepreneurship are part of sustainable entrepreneurship [26]. Unlike ecopreneurship and social entrepreneurship, sustainable entrepreneurship focuses on all three aspects: economic, social, and environmental value and it aims to achieve the "triple bottom line" that benefits people, the planet, and profit [27]. For instance, Honest Tea was set up in the USA by Seth Goldman and Barry Nalebuff in 1997 to provide low calorie organic health drinks to customers. Their ingredients are USDA (United States Department of Agriculture) organic and Fair Trade certified. Their business has grown rapidly, and they were acquired by Coca-Cola in 2011.

Figure 1 presents the conceptual model of sustainable entrepreneurship that was used to inform the study and interpret the review results. This conceptual model was adapted from the model of social entrepreneurship developed by Austin et al. [17]. At the center of the model are the three interdependent variables: opportunity, people, and capital. People (e.g., entrepreneurs and partners) discover an opportunity and mobilize capital (e.g., financial, social, and technological resources/capital) to create economic, social, and environmental value proposition. The contextual forces (e.g., regulations, political/socio/cultural context, macro economy, demographics) also enable and constrain the sustainable value proposition of the entrepreneurs.

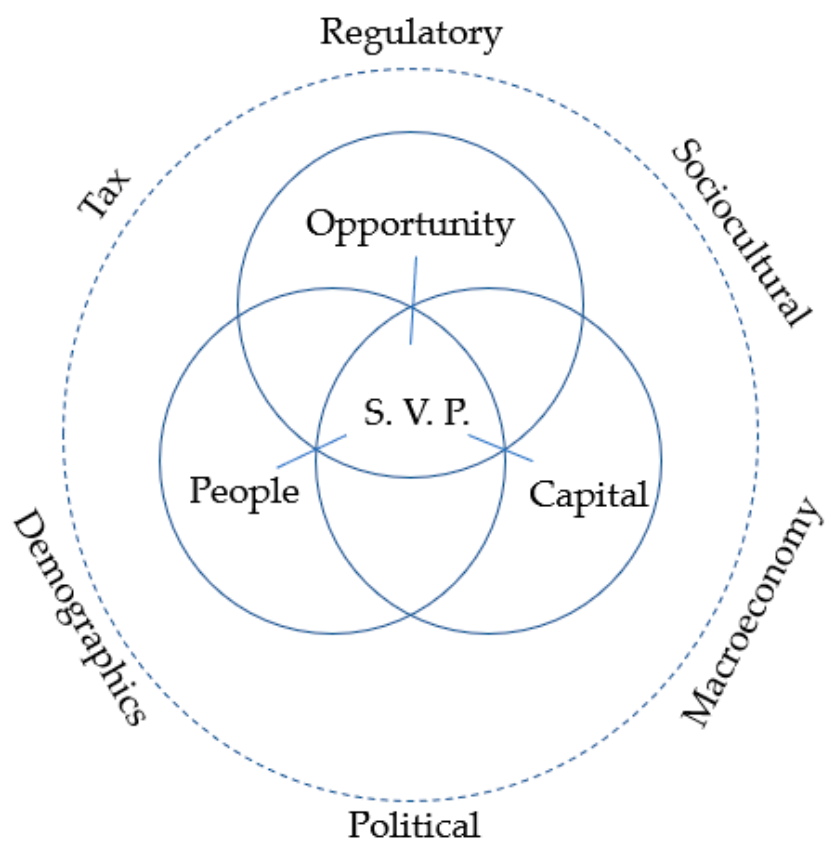

S. V. P. = Sustainable Value Proposition

Figure 1. Conceptual model of sustainable entrepreneurship adapted from Austin et al. [17]. 
Similar to theoretical and empirical research on entrepreneurship, sustainable entrepreneurship scholars have tried to examine 'how opportunities to bring into existence future goods and services are discovered, created, and exploited, by whom, and with what economic, psychological, social, and environmental consequences' [7] (p. 35). Sustainable entrepreneurship scholars began to examine the sources of entrepreneurial opportunities and they argued that 'market imperfection' led to challenges and opportunities for sustainable entrepreneurs to solve the problem [7]. Others explored the role of the personality of sustainable entrepreneurs and their behaviors, entrepreneurial processes, and the social/sustainable opportunities [23]. More recently, sustainable entrepreneurship scholars examined how sustainable entrepreneurship practices are enacted and maintained over time $[28,29]$ and also how training and education can foster sustainable entrepreneurship [30,31].

\section{Method and Materials}

Advances in computer technologies and the method of bibliometric review enable researchers to perform data mining, science mapping, social network analysis, and textual analysis of a knowledge base $[15,16,32]$. Entrepreneurship scholars have applied bibliometric analysis to subdomains such as social entrepreneurship [33,34], rural entrepreneurship [35], entrepreneurship in family firms [36], women's entrepreneurship [37], and new ventures [38]. This review used science mapping to analyze research trends in sustainable entrepreneurship.

\subsection{Data Collection}

Science mapping is a subset of systematic reviews of research. The source of this review's database was the Scopus index. According to Mongeon and Paul-Hus [39], Scopus has a better coverage of journals than the Web of Science (WOS) in management subjects, which made it a suitable choice for this review of research on sustainable entrepreneurship [40].

The author selected journal articles, conference papers, books, book chapters, editorials, and reviews indexed in Scopus so as to capture a broad spectrum of research. The duration of this review is from 1996 (i.e., the earliest document on sustainable entrepreneurship identified in the SCOPUS search) to March 2019. The author included documents that explicitly focused on both sustainability and entrepreneurship. Therefore, documents that emphasized either sustainability or entrepreneurship were excluded. For instance, documents that studied the role of entrepreneurship in regional economic development which mentioned sustainability in passing were not selected into the review database.

The author adopted the PRISMA (Preferred Reporting Items for Systematic Reviews and Meta-Analyses) approach [41] for documenting the search procedures used in this review. First, the first keyword search was (TITLE-ABS-KEY ("sustainable") AND ("entrepreneurship"), and the second keyword search was (TITLE-ABS-KEY ("sustainability") AND ("entrepreneurship"). This former search yielded 2036 documents, whilst the latter yielded 1339 documents. The two search results were then compared, and it was found that the 1339 documents from the keyword "Sustainability" AND "entrepreneurship" seemed to be more relevant (as mentioned earlier in the screening criteria) to the sustainable entrepreneurship literature than the 2036 search result. That is, many of the documents in the 2036 search result set focused on either the entrepreneurship area or sustainability area but did not directly address sustainable entrepreneurship. Thus, the author decided to use the 1339 search results as documents for the initial database.

In the next step, the screening process aimed to exclude ineligible documents (e.g., erratum, corrigendum, and conference proceedings that were too broad in scope) and duplicated items in SCOPUS, which totaled 14 documents (see Figure 2). Then, in the eligibility checking process, the author checked the relevance of the remaining 1325 documents by reading the titles, keywords, and abstracts of the remaining documents. The criteria for excluding the documents were: (1) sustainability and/or entrepreneurship were mentioned only in general terms; (2) sustainable entrepreneurship was not the primary focus of the document. After the relevance checking, 712 documents remained in the final review database (see Figure 2). 
Total documents identified in the initial Scopus database search. $(\mathrm{n}=1339)$
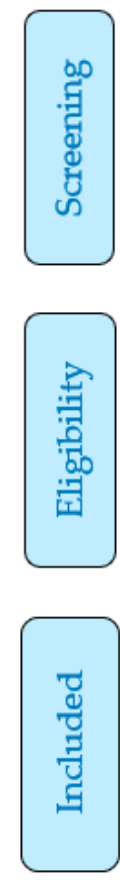

Documents excluded based on application of exclusion criteria $(\mathrm{n}=14)$

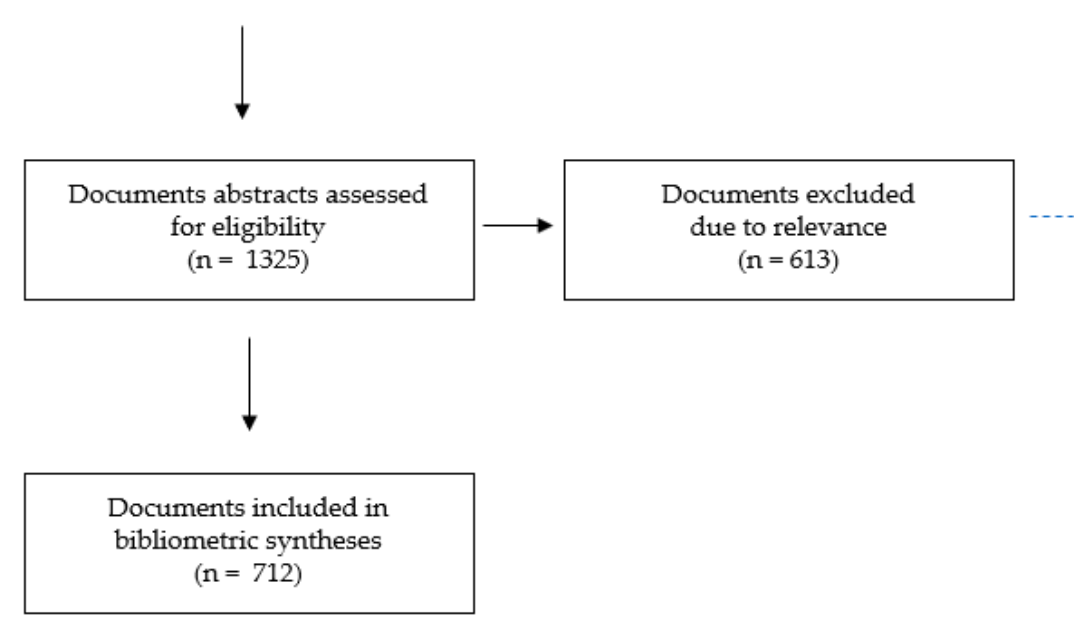

Erratum, corrigendum and conference proceedings that were too broad in scope and duplicated items

Figure 2. PRISMA flow diagram detailing steps in the identification and screening of sources (adapted from Moher et al., 2009 [41]).

\subsection{Data Extraction and Analysis}

After the 712 SCOPUS documents were identified, the author exported the bibliographic metadata associated with them into an Excel file. These data included the author names, their affiliations, titles, keywords, abstracts, and citation numbers. The author then uploaded this file into the VOSviewer software (version 1.6.10) for the next stage of the bibliometric analysis. Another copy of the csv file was saved in Excel for use in the descriptive data analysis.

Descriptive statistics were created to describe the landscape of the sustainable entrepreneurship knowledge corpus. For bibliometric analysis, VOSviewer software was used to analyze the citation patterns, intellectual structure, and subjects studied in the sustainable entrepreneurship research. For instance, citation analysis was conducted to identify high-impact documents and authors. The author also conducted co-citation analysis $[15,42]$ in order to measure similarity between authors, journals, and documents. Keyword co-occurrence analysis was used to analyze the most prevalent and emerging topics within the sustainable entrepreneurship knowledge base [16,17].

\section{Results}

\subsection{Broad Trends in the Sustainable Entrepreneurship Literature}

The Scopus-indexed knowledge base of 712 documents consisted of 472 journal articles, 93 conference proceedings, 71 book chapters, 32 reviews, 21 books, and 23 other documents (e.g., editorials). The literature on sustainable entrepreneurship slowly grew in the late 1990s with the publication of three documents, 61 documents during the 2000s, and 648 documents between 2010 and 2019 
(see Figure 3). These data show a modest but rapidly growing literature. The dramatic increase in scholarly interest in sustainable entrepreneurship over the past 10 years suggest that this literature is experiencing a growth spurt due to increased scholarly interest in sustainability issues across education and management domains [43-45].

Documents by year

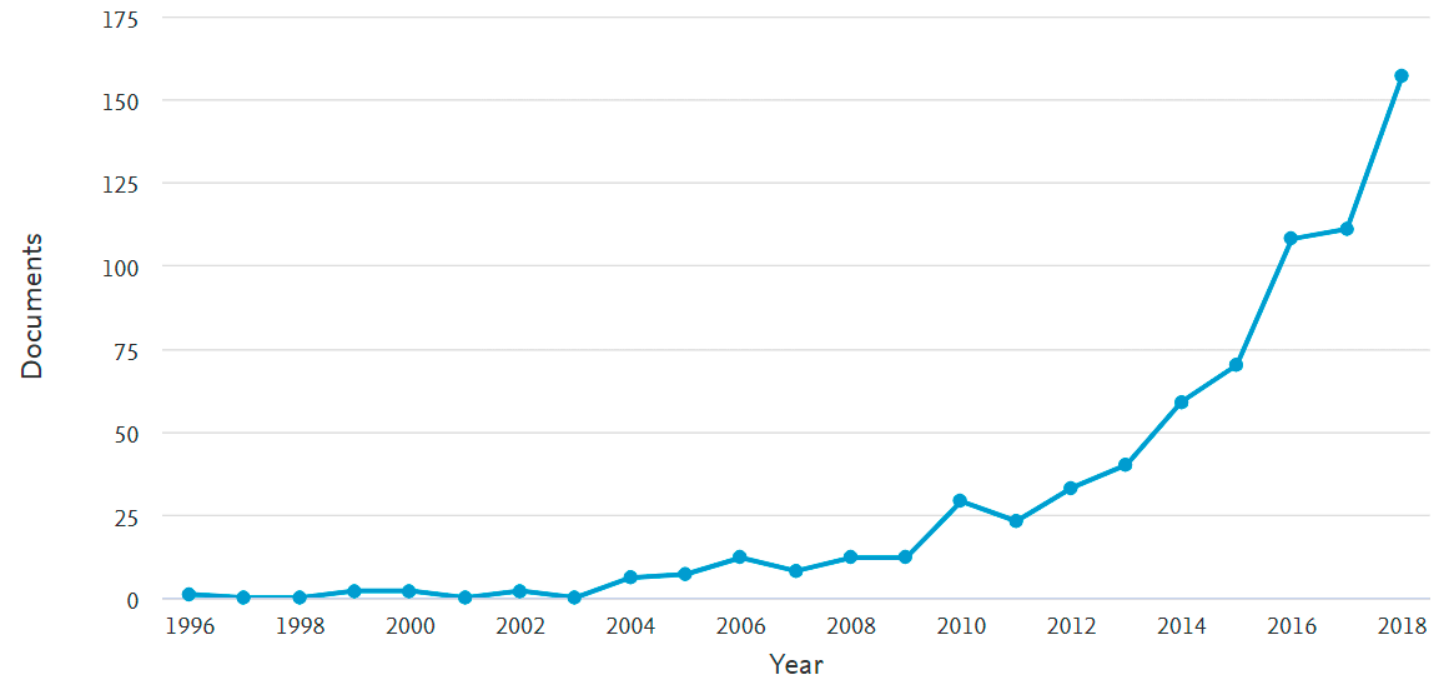

Figure 3. Evolution of publications on sustainable entrepreneurship literature, 1996-2019 (n = 712).

The data trend in Figure 4 shows that sustainable entrepreneurship publications are centered in the USA, UK, Netherlands, Germany, and Canada. Scholars located in these five societies produced 370 of the 712 documents (52\%) of the Scopus-indexed knowledge base on sustainable entrepreneurship. This knowledge production trend is in line with the trend in the management literature in which Anglo-American scholars have dominated in the English language international publication [43-45]. Therefore, the high proportion of sustainable entrepreneurship knowledge produced by scholars in these Western countries may not necessarily signify higher interest in sustainability issues, but could be interpreted as a phenomenon of broader knowledge production trends [43-45].

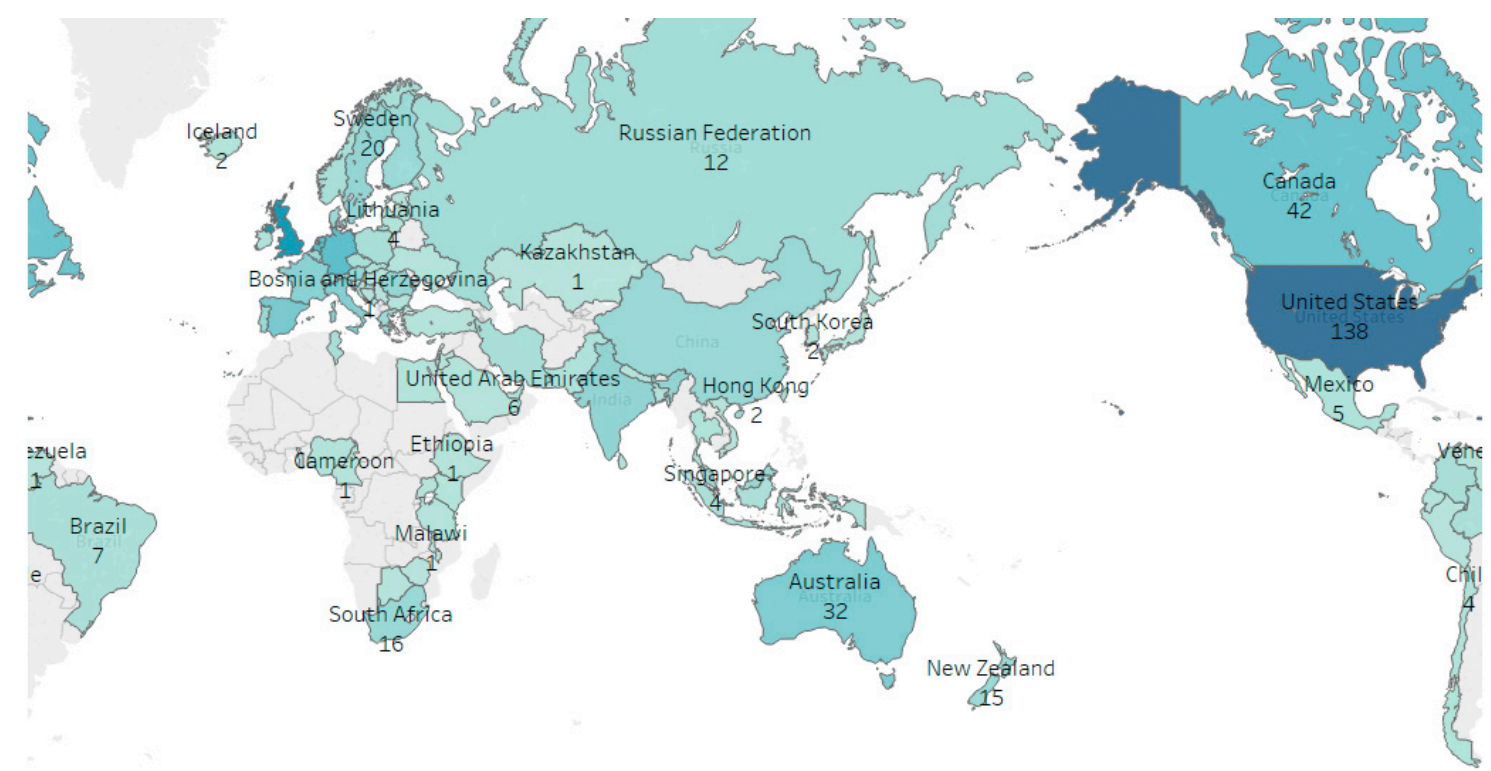

Figure 4. Worldwide dispersion of the sustainable entrepreneurship literature, 1996-2019 ( $\mathrm{n}=712$ ). 
Despite the dominance of scholarship from Western societies, the sustainable entrepreneurship knowledge corpus also shows growing diversity in authorship patterns. As indicated in Figure 4, the sustainable entrepreneurship literature also includes publications from Europe (e.g., Spain, Italy, France, Sweden, Lithuania), Asia (e.g., India, China, Malaysia, Indonesia, Taiwan), Africa (e.g., Tunisia, Nigeria, Kenya, South Africa, Botswana), and Latin America (e.g., Mexico, Chile, Ecuador, Jamaica, Brazil). This highlights the growing global interest in entrepreneurship as a means of fostering sustainability in both economically developed and developing societies.

\subsection{Analysis of High-Impact Journals, Authors, and Documents}

This section analyzes the sources, scholars, and documents contained in the Scopus-indexed sustainable entrepreneurship knowledge base. These analyses offer insight into patterns of knowledge production and dissemination on sustainable entrepreneurship.

\subsubsection{High-Impact Journals in Sustainable Entrepreneurship}

Table 1 shows that the 20 most highly cited journals published 222 articles, representing 31\% of the full sustainable entrepreneurship knowledge base. The foci of scholarship on sustainable entrepreneurship are relatively broad when looking at the journals that publish the sustainable entrepreneurship articles. The top 20 journals in Table 1 cover a wide range of topics such as business and management; geography, planning, and development; industrial and manufacturing engineering, law, organizational behavior, and human resource management; economics and development. Thus, this suggests that sustainable entrepreneurship scholarship is multidisciplinary and encompasses many types of organisations (e.g., start-ups, for-profit and nonprofit organizations, and corporates) in many sectors (e.g., engineering and production, tourism, nonprofit sector, and non-governmental organizations).

Table 1. High-impact journals in the field of sustainable entrepreneurship.

\begin{tabular}{|c|c|c|c|c|c|}
\hline Rank & Source & Domain & Number & Scopus Citations & Scopus Quartile \\
\hline 1 & Journal of Business Venturing & Business \& Management & 12 & 2813 & Q1 \\
\hline 2 & Business Strategy and the Environment & Geo, Planning \& Development & 12 & 895 & $\hat{\mathrm{Q} 1}$ \\
\hline 3 & Journal of Cleaner Production & Industrial and Manu Eng & 23 & 604 & Q1 \\
\hline 4 & Greener Management International ${ }^{1}$ & Environmental Science & 8 & 470 & $\mathrm{~N} / \mathrm{A}$ \\
\hline 5 & Journal of Sustainable Tourism & Geo, Planning \& Development & 6 & 377 & Q1 \\
\hline 6 & Journal of Management Studies & Business \& Management & 8 & 264 & Q1 \\
\hline 7 & Journal of Business Ethics & Law & 9 & 219 & Q1 \\
\hline 8 & Organization and Environment & Org Behavior and HRM & 5 & 208 & Q1 \\
\hline 9 & Sustainability (Switzerland) & Geo, Planning \& Development & 53 & 204 & Q1 \\
\hline 10 & Entrepreneurship and Sustainability Issues 2 & Business \& Management & 15 & 110 & $\mathrm{~N} / \mathrm{A}$ \\
\hline 11 & CSR and Environmental Management & Environmental Science & 5 & 81 & Q1 \\
\hline 12 & Int'l Jnl of Entre Behaviour and Research & Business \& Management & 10 & 47 & Q1 \\
\hline 13 & Journal of Enterprising Communities & Business \& Management & 8 & 44 & Q2 \\
\hline 14 & Journal of Social Entrepreneurship & Business \& Management & 8 & 38 & $\mathrm{Q} 1$ \\
\hline 15 & Journal of Small Business and Entre ${ }^{3}$ & Business \& Management & 7 & 24 & $\mathrm{~N} / \mathrm{A}$ \\
\hline 16 & International Jnl of Entre and Small Business & Business \& Management & 6 & 18 & $\mathrm{Q} 2$ \\
\hline 17 & International Journal of Entre Venturing & Business \& Management & 8 & 13 & Q3 \\
\hline 18 & Emerging Directions in Social Entre 4 & Business \& Management & 5 & 7 & N/A \\
\hline 19 & ASEE Annual Conference Proceedings & Engineering Education & 7 & 5 & $\mathrm{~N} / \mathrm{A}$ \\
\hline 20 & Proceedings of IESM 2015 & Industrial and Manu Eng & 7 & 2 & $\mathrm{~N} / \mathrm{A}$ \\
\hline
\end{tabular}

The quality of sustainable entrepreneurship scholarship can also be assessed through reference to the Scopus Quartiles. Data in Table 1 indicate that 11 (i.e., 55\%) of the top 20 most highly cited journals were ranked in Q1, two (i.e., 10\%) in Q2, and one (i.e., 5\%) in Q3. One journal (Greener Management International) was, however, not ranked because it no longer exists, and the other two journals (Entrepreneurship and Sustainability Issues and Journal of Small Business and Entrepreneurship) started to be indexed and covered by the Scopus Index in 2017 and 2016, respectively. From the 
analysis of the Scopus quartile rankings as a proxy for research quality, it suggests that the most cited publications on sustainable entrepreneurship have featured in Q1 and Q2 journals.

\subsubsection{High-Impact Authors in Sustainable Entrepreneurship}

The most prolific scholars, as measured by the number of Scopus documents in the field of sustainable entrepreneurship (not tabled), have been Schaltegger (7), Wagner (5), Hansen (5), Lans (5), and Lourenço (5). However, Table 2 indicates that the highest-impact scholars writing on sustainable entrepreneurship, as measured by "total Scopus citations", are Mair (1435), Austin (1067), Stevenson (1067), Wei-Skillern (1067), and Marti (1012). It should be noted that their highly cited documents tended to focus on 'social entrepreneurship', a sub-theme within sustainable entrepreneurship. The most influential scholars in the sustainable entrepreneurship knowledge base, whose work explicitly addresses the topic of sustainable entrepreneurship, are Schaltegger (568), Wagner (537), Dean (529), Cohen (485), and McMullen (430).

Table 2. High-impact authors on sustainable entrepreneurship, 1996-2019 (n = 712).

\begin{tabular}{clccc}
\hline Rank & Scholar & Society $^{\mathbf{1}}$ & Number & Scopus Citations \\
\hline 1 & Mair J. & Spain & 4 & 1435 \\
2 & Austin J. & USA & 1 & 1067 \\
3 & Stevenson H. & USA & 1 & 1067 \\
4 & Wei-Skillern J. & USA & 1 & 1067 \\
5 & Martí I. & Spain & 1 & 1012 \\
6 & Zahra S. & USA & 2 & 739 \\
7 & Gedajlovic E. & Canada & 1 & 698 \\
8 & Neubaum D. & USA & 1 & 698 \\
9 & Shulman J. & USA & 1 & 698 \\
10 & Schaltegger S. & Germany & 7 & 568 \\
11 & Wagner M. & Germany & 5 & 537 \\
12 & Dean T. & USA & 2 & 529 \\
13 & Peredo A. & Canada & 2 & 529 \\
14 & Mclean M. & Canada & 1 & 516 \\
15 & Cohen B. & Spain & 4 & 485 \\
16 & Mcmullen J. & USA & 2 & 430 \\
17 & Hansen E. & Austria & 5 & 424 \\
18 & Winn M. & Canada & 1 & 384 \\
19 & Seelos C. & Belgium & 1 & 365 \\
20 & York J. & USA & 4 & 356 \\
\hline
\end{tabular}

\footnotetext{
${ }^{1}$ Society is the country/institution affiliation of the authors when they published the documents. For instance, Mair was based in Spain, but now she is currently based in Germany.
}

It was noted that the number of citations of sustainable entrepreneurship scholars (e.g., Schaltegger (568), Wagner (537), Dean (529)) is relatively low, compared to social entrepreneurship scholars (e.g., Mair (1435), Austin (1067), and Stevenson (1067)). This may be partly due to the different temporal trends of the topics. Research on social entrepreneurship can be considered the formative vein from which the broader line of inquiry on sustainable entrepreneurship has grown. Moreover, only a few of the top 20 most highly cited authors have been classified as the top entrepreneurship scholars globally. Thus, these findings can be interpreted that sustainable entrepreneurship is still an emerging knowledge base.

\subsubsection{High-Impact Documents in Sustainable Entrepreneurship}

The analysis of influential documents in the sustainable entrepreneurship knowledge base also revealed a dominance of scholars from Western societies. More specifically, the most highly cited documents in Table 3 are from the USA, Canada, Europe, and New Zealand. Among the top 20 most highly cited documents, no document was authored in a developing society. 
Table 3. High-impact documents by Scopus citations $(\mathrm{n}=712)$.

\begin{tabular}{clcccc}
\hline Rank & \multicolumn{1}{c}{ Paper } & Society & SE Focus & Kind of Paper & Scopus Citations \\
\hline 1 & Austin et al. (2006) [17] & USA & Soc Entre & Conceptual & 1067 \\
2 & Mair \& Martí (2006) [23] & SPAIN & Soc Entre & Conceptual & 1012 \\
3 & Zahra et al. (2009) [24] & USA & Soc Entre Types & Conceptual & 698 \\
4 & Peredo \& McLean (2006) [55] & CAN & Soc Entre & Review & 516 \\
5 & Dean \& McMullen (2007) [47] & USA & SE antecedents & Conceptual & 395 \\
6 & Cohen \& Winn (2007) [7] & CAN & SE antecedents & Conceptual & 384 \\
7 & Seelos \& Mair (2005) [25] & SPAIN & Soc Entre & Conceptual & 365 \\
8 & Schaltegger \& Wagner (2011) [26] & GER & SE & Conceptual & 342 \\
9 & Hall et al. (2010) [56] & CAN & SE & Review & 299 \\
10 & Ateljevic \& Doorne (2000) [57] & NZ & Eco-Entre & Conceptual & 287 \\
11 & Hockerts \& Wüstenhagen (2010) [48] & DEN & SE & Conceptual & 271 \\
12 & Klewitz \& Hansen (2014) [58] & GER & Sust SMEs & Review & 231 \\
13 & Marsden \& Smith (2005) [53] & UK & Eco-Entre & Empirical & 188 \\
14 & York \& Venkataraman (2010) [59] & USA & SE antecedents & Conceptual & 179 \\
15 & Kuckertz \& Wagner (2010) [51] & GER & SE & Empirical & 155 \\
16 & Parrish (2010) [54] & UK & SE \& org & Empirical & 153 \\
17 & Young \& Tilley (2006) [49] & UK & SE & Conceptual & 153 \\
18 & Meek et al. (2010) [46] & USA & SE & Empirical & 134 \\
19 & Pacheco et al. (2010) [50] & USA & SE & Conceptual & 134 \\
20 & Larson (2000) [52] & USA & Sus Innov & Empirical & 134 \\
\hline
\end{tabular}

${ }^{1}$ Based on 1st author only. SE $=$ Sustainable entrepreneurship.

The highly cited documents on sustainable entrepreneurship include a mix of conceptual (12), empirical (5), and review (3) papers. This set of influential documents have focused on defining and developing models of sustainable entrepreneurship [7,46-50] and differentiating it from related concepts such as environmental entrepreneurship, social entrepreneurship, and corporate social responsibility and sustainability innovation $[17,24-26]$.

As for the empirical documents, two articles used quantitative methods [46,51] and the others qualitative methods (i.e., case studies) [52-54]. Only one of the two quantitative articles used a large sample size (519 samples) [51]. The topics of these quantitative studies were the antecedents (e.g., sustainability orientation, training and work experience [51], and role of norms [46]) of entrepreneurial intention. At the same time, the qualitative studies illustrated the success cases of sustainable entrepreneurship and sustainability innovation (e.g., sustainable operation of a Kayak manufacturer [52] and sustainable entrepreneurship networks in the UK and Dutch agri-food business [53]). The findings seem to suggest that the sustainable entrepreneurship knowledge base is in the nascent stage, in which the influential documents are still focusing on the foundation concepts and testing theoretical relations among these key constructs, as well as deriving theoretical insights from case studies.

The author followed the above analysis with "document co-citation analysis" (DCA) [16,17]. DCA examined the reference lists of the 712 documents contained in the sustainable entrepreneurship review database in order to identify references (i.e., documents) that occur together in the reference lists. Documents that are frequently "co-cited" (i.e., cited together in reference lists) are considered to share some commonality in theoretical perspective. Notably, since these "co-cited documents" are drawn from the reference lists of the sustainable entrepreneurship documents, they are not limited to the Scopus database. Thus, DCA offers a different perspective on scholarly influence than direct citation analysis, which only measures influence on other Scopus documents.

The DCA results in Table 4 show a relatively low level of document co-citation with respect to the "most influential documents" (i.e., 15 to 77 co-citations). This reaffirms the earlier conclusion that the sustainable entrepreneurship literature is still in an emergent state of development. The geographical distribution of the top co-cited documents reprises the patterns noted in the other prior analyses. The main journal outlets of the highly co-cited documents are top-tier management journals (e.g., Academy of Management Review, Academy of Management Journal, and Journal of Management), leading entrepreneurship journals (e.g., Journal of Business Venturing, Entrepreneurship: Theory and 
Practice), and geography and environmental science journals (e.g., Business Strategy and Environment, Greener Management International).

Table 4. High-impact SE documents by co-citations.

\begin{tabular}{|c|c|c|c|c|c|}
\hline Rank & Paper & Society & Kind & Topic & Co-Citations \\
\hline$* 1$ & Dean \& McMullen (2007) [47] & USA & Conceptual & Sust Entre & 77 \\
\hline$* 2$ & Hall et al. (2010) [56] & CAN & Review & Sust Entre & 58 \\
\hline$* 3$ & Schaltegger \& Wagner (2011) [26] & GER & Conceptual & Sust Entre \& Innov & 55 \\
\hline 4 & Cohen et al. (2008) [63] & CAN & Conceptual & Sust Entre & 49 \\
\hline * 5 & Mair \& Marti (2006) [23] & SPAIN & Conceptual & Soc Entre & 46 \\
\hline$* 6$ & Hockerts \& Wustenhagen (2010) [48] & DEN & Conceptual & Sust Entre & 43 \\
\hline 7 & Shane \& Venkataraman (2000) [3] & USA & Conceptual & Entre & 39 \\
\hline$* 8$ & Cohen \& Winn (2007) [7] & CAN & Conceptual & Sust Entre & 38 \\
\hline$* 9$ & Parrish (2010) [54] & UK & Empirical & Sust Entre & 37 \\
\hline$* 10$ & Pacheco et al. (2010) [50] & USA & Conceptual & Sust Entre & 36 \\
\hline * 11 & Austin et al. (2006) [17] & USA & Conceptual & Soc Entre & 33 \\
\hline * 12 & Kuckertz \& Wagner (2010) [51] & GER & Empirical & Sust Entre & 31 \\
\hline 13 & Patzelt \& Shepherd (2011) [64] & GER & Conceptual & Sust Entre & 29 \\
\hline 14 & Eisenhardt (1989) [61] & USA & Methodology & Case Method & 27 \\
\hline *15 & Zahra et al. (2009) [24] & USA & Conceptual & Soc Entre & 25 \\
\hline *16 & Larson (2000) [52] & USA & Empirical & Sust Innov & 24 \\
\hline 17 & Eisenhardt \& Graebner (2007) [62] & USA & Methodology & Case Method & 18 \\
\hline * 18 & Peredo \& Mclean (2006) [55] & CAN & Review & Soc Entre & 17 \\
\hline 19 & Schumpeter (1934) [1] & USA & Conceptual & Entre & 17 \\
\hline 20 & Barney (1991) [60] & USA & Conceptual & Strategy & 15 \\
\hline
\end{tabular}

* Signifies a highly co-cited document that also appeared in the top 20 highly cited documents (Table 3).

If we step back and review the findings from these complementary citation analyses, the findings highlight 13 documents that feature on both lists $[7,17,23-26,47,48,50,51,55,56]$. Thus, the author concludes that these documents have the greatest influence on the evolution of sustainable entrepreneurship scholarship. Three nonoverlapping documents in the co-citation list represent boundary-spanning literature drawn from entrepreneurship (Schumpeter (1934) [1], Shane \& Venkataraman (2000) [3]) and strategy literature (Barney, (1991) [60]). The DCA also suggests that the case method of Eisenhardt [61,62] also appears to have great influence on sustainable entrepreneurship scholarship.

The author further noted that in Table 4 , the top three co-cited documents $[26,47,56]$ which directly featured the sustainable entrepreneurship topics, were ranked 5th, 8th, and 9th in the top 20 most highly cited sustainable entrepreneurship documents (Table 3) behind its sub-theme-the social entrepreneurship documents $[17,23,24]$. On the other hand, the top three most highly cited documents $[17,23,24]$ of the social entrepreneurship sub-theme were ranked 5th, 11th, and 15th in the co-citation analysis (Table 4). Thus, the DCA seems to identify influential documents $[7,47,56]$ of the sustainable entrepreneurship theme and its sub-themes (e.g., social entrepreneurship $[17,23,24]$ and sustainability innovation [26,52]) among the knowledge base better than the citation analysis.

\subsection{Intellectual Structure of the Sustainable Entrepreneurship}

This section of the paper examines the "intellectual structure" of the sustainable entrepreneurship knowledge corpus. Author co-citation analysis (ACA) was used to create a co-citation map that portrays relationships among highly co-cited authors [15,65]. As noted earlier, co-citation analysis assumes that highly co-cited authors or documents bear a kind of intellectual similarity. ACA uses a technique known as visualization of simulations or VOS which produces a co-citation map capable of revealing the intellectual structure of the field of study [16,59].

Figure 5 displays an author co-citation map on which the nodes represent different scholars. The size of a bubble signifies the level of author co-citations, with larger bubbles indicating higher levels of co-citation. The links that connect nodes stand for co-citations of those authors by other authors. The ACA map categorizes scholars into colored groups (or clusters) which can be interpreted as the "Schools of Thought" or "sub-themes" that comprise the SE literature $[15,16,66]$. Scholars who 
are grouped in the same colored cluster would normally share theoretical perspectives and research interests $[15,65]$. Thus, Schools of Thought can be interpreted to represent "research traditions" within a field of study.

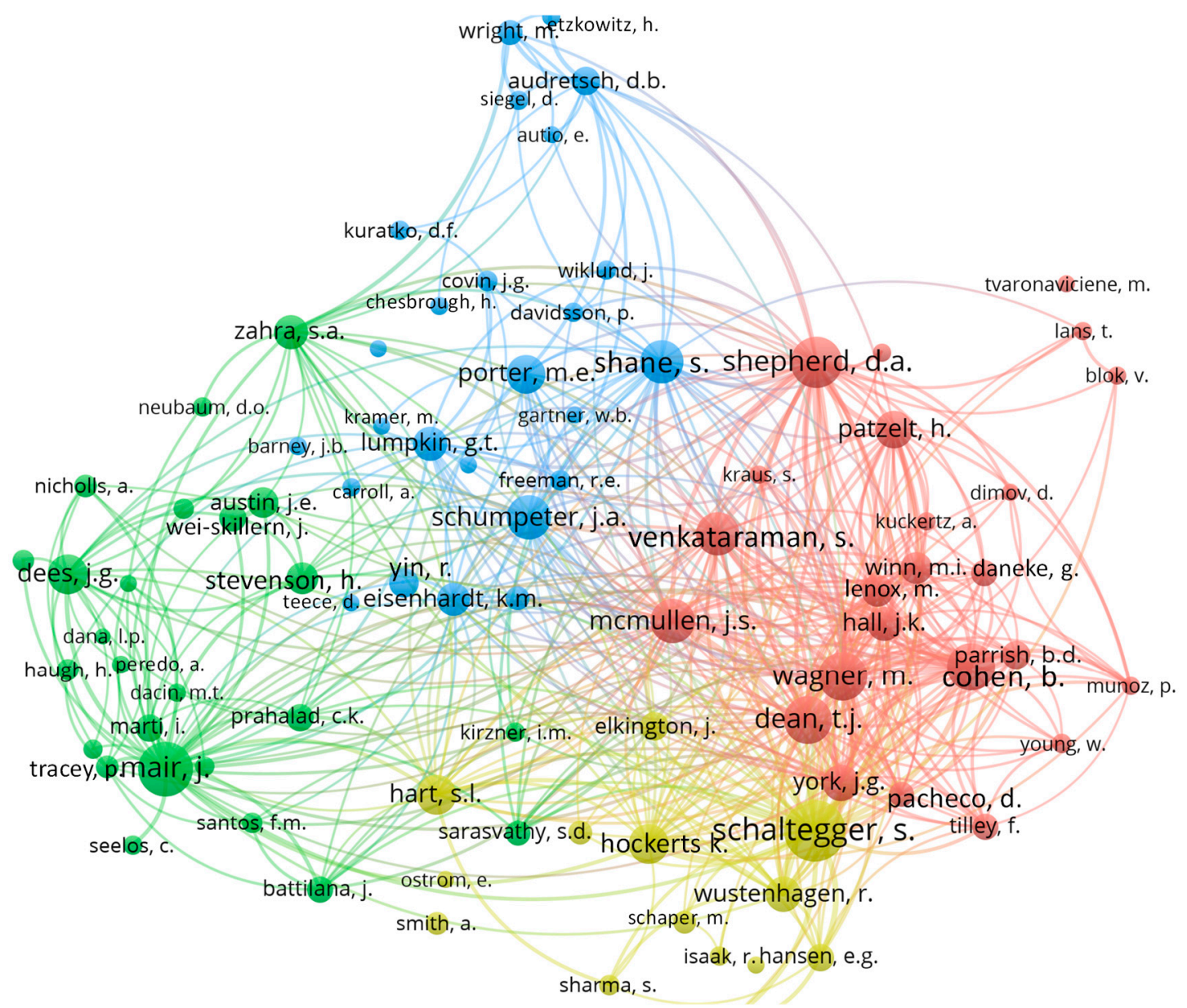

Figure 5. Four clusters representing the intellectual structure of SE research.

ACA identified an author co-citation network consisting of 35,353 authors located in the reference lists of the 712 documents contained in the review database. Using a threshold of 45 co-citations, ACA identified 88 authors who met this criterion. These authors are displayed in the ACA map shown in Figure 5. The most highly co-cited authors in the sustainable entrepreneurship literature are Schaltegger (255), Mair (220), Wagner (191), Shepherd (204), Wagner (191), and Cohen (183) (not tabled). As shown in Figure 5, the intellectual structure of the sustainable entrepreneurship literature is comprised of four author clusters or Schools of thought. Both the unity and density of links connecting the four clusters suggest that these Schools are distinctive but reciprocal in their conceptual grounding.

While scholars comprising three of the Schools (i.e., the red, yellow, and green clusters) have published extensively on sustainable entrepreneurship and its sub-themes, the fourth School (i.e., the blue cluster) is comprised of 18 authors working in the field of Entrepreneurial Strategy. Authors comprising this School include scholars associated with two research areas of "entrepreneurship" and "strategy." Those associated with entrepreneurship research include Shane [3], Kuratko [67], Covin [68], Wiklund [69], Lumpkin [70], Etzkowitz [71], Audretsch [72], and Schumpeter [1]. Scholars associated with strategy, such as Porter [73], Freeman [74], Carroll [75], and Siegel [76] are known for their research on stakeholder participation [73,74] and corporate social responsibility [75,76]. The emergence of this School of Thought on the map reflects the frequent co-citation of scholarship on entrepreneurship and strategy by authors specializing in sustainable entrepreneurship. Notably, this cluster also includes scholars known for publications on 
research methods, such as Eisenhardt (qualitative case study) [61,62] and Yin (case method) [77]). Due to the centrality of their nodes position in the map, it may be interpreted that sustainable entrepreneurship scholars frequently adopt these qualitative methods in their empirical research.

The other three Schools focus explicitly on selected sub-themes of sustainable entrepreneurship, with the red and green clusters representing the largest groups of authors (23 and 22 authors, respectively). The red cluster, concerned with Sustainable Entrepreneurship, includes scholars such as Wagner [51], Dean [47], Cohen [7,63], Shepherd [78], Venkataraman [59], and McMullen [47]. These scholars are linked because their research examines how entrepreneurship can achieve economic, social, and environmental value $[7,26,47]$. Several authors from this cluster (e.g., Cohen, Winn, Wagner, Dean, and McMullen) authored works that were among the top co-cited documents in Table 4. Based on their central location and dense links to authors across all four clusters, McMullen and Venkataraman represent key "boundary spanning" authors linking the sustainable entrepreneurship cluster to the other three Schools of Thought. This may be due to their foci of research on both entrepreneurship and sustainable entrepreneurship topics $[4,59,78]$.

The green cluster can be termed the Social Entrepreneurship School. Scholars working within this School (e.g., Mair [23,25], Dees [79], Marti [23], Wei-Skillern [17], and Peredo [55]) have studied how entrepreneurs use innovation to drive the social mission of organizations $[17,23,25,55]$. Several scholars located in this School were identified earlier as highly cited authors in this literature (see Table 2) because the research in the sub-theme of social entrepreneurship predates that of the sub-theme of sustainable entrepreneurship.

Finally, the yellow cluster represents the Sustainability Innovation School. Led by Schaltegger [26], Hockerts [48], Hansen [58], and Hart [80], this is the smallest of the four Schools (i.e., 11 authors). Nonetheless, its influence is quite substantial, as indicated by the size of several authors' nodes. This group of scholars has investigated topics such as innovation and corporate sustainability [81], business models for sustainability [82,83], and sustainable policy $[26,48,52]$.

\subsection{Topics Studied in Sustainable Entrepreneurship}

This section employed keyword co-occurrence analysis to reveal key themes and topics within the sustainable entrepreneurship knowledge base. According to Zupic and Cater [15], co-word analysis identifies words that are frequently co-occurring in the titles, abstracts, and indexes of documents in the review database. Co-word analysis was used to identify the most frequently occurring keywords in this literature [15]. This analysis would offer insight into broad topical trends within the literature as a whole.

The most frequently occurring keywords in the sustainable entrepreneurship literature were sustainability (254 occurrences), sustainable development (192), entrepreneurship (127), social entrepreneurship (115), entrepreneur (105), sustainable entrepreneurship (90), innovation (78), social enterprise (34), small and medium-sized enterprise (25), education (23), economics (22), corporate social responsibility (22), economic development (20), student (19), curricula (19), and business (19). These frequently occurring keywords offer insight into the subjects of studies that describe the SE literature since its emergence almost 30 years ago.

In order to synthesize the frequently co-occurring keywords into themes, VOSviewer was used to create a co-word map (see Figure 6). The topics studied most frequently by SE scholars cohere into four themes. The first theme, sustainable entrepreneurship (blue cluster), focuses on how sustainable entrepreneurs used their ventures and innovations to create economic, social, and environmental value for societies $[28,29,84-86]$. The sub-set keywords of this theme include: sustainable entrepreneurs, ecopreneur, business, business model, innovation, CSR, triple bottom line, ethics, corporate sustainability, and sustainable business. The second theme, social entrepreneurship (red cluster), examines how social entrepreneurs and social enterprises address social issues and create social changes [87-89]. The sub-set keywords of this theme are: social enterprise, cooperation, stakeholders, social capital, social impact, social change, and rural area. 


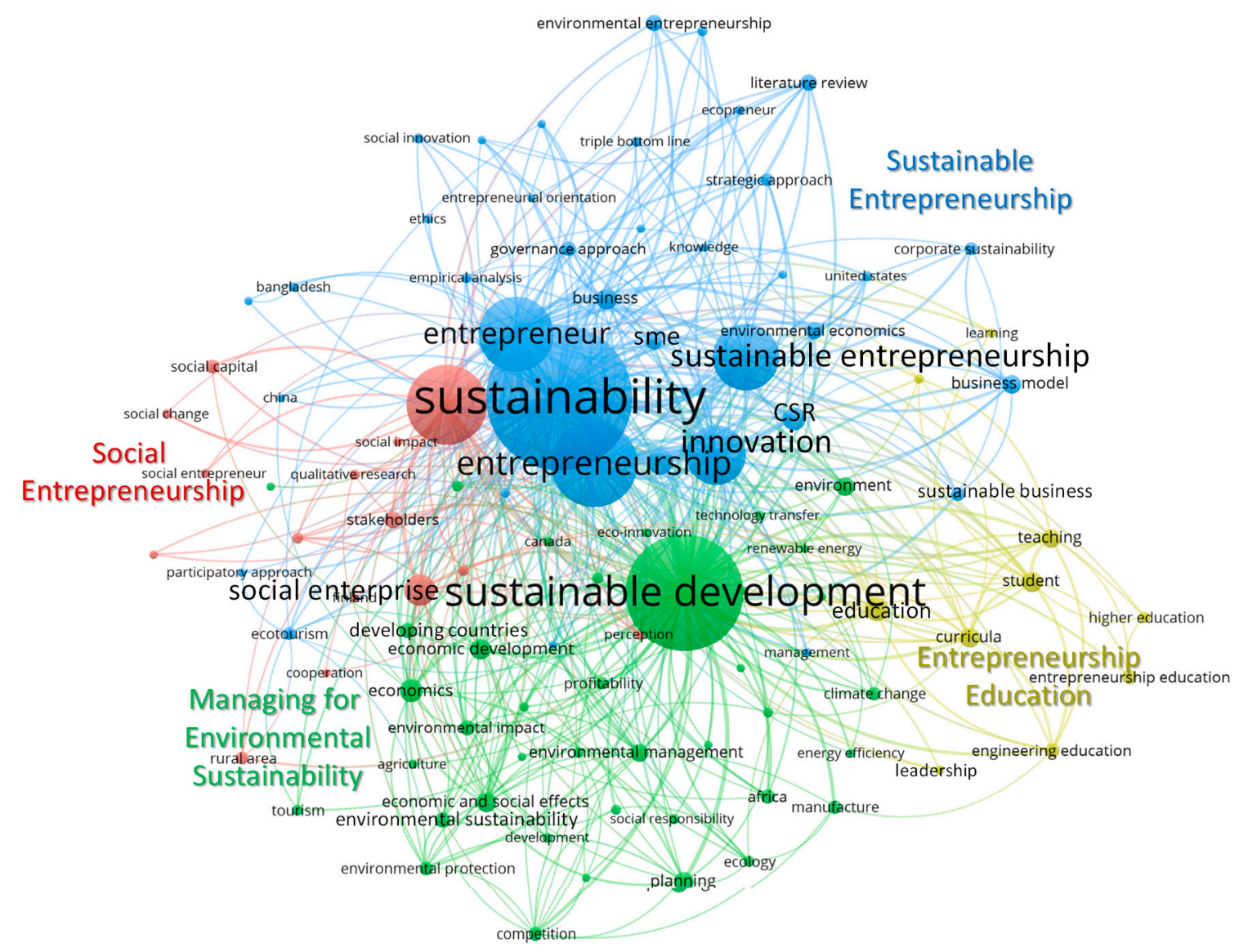

Figure 6. Subject analysis of sustainable entrepreneurship literature.

The third theme, managing for environmental sustainability (green cluster), investigates how businesses and entrepreneurs use technology and innovation to drive sustainable development in various sectors $[82,90,91]$. The sub-set keywords of this theme encompass: economic development, environmental management, eco-innovation, technology transfer, renewable energy, climate change, agriculture, tourism, developing countries, energy efficiency, environmental sustainability, economic and social effects. The fourth theme, entrepreneurship education (yellow cluster), explores how entrepreneurship education can be used to support sustainable development $[30,31,54,92]$. The sub-set keywords of this theme include: education, teaching, curricula, student, engineering education, higher education, curricular, learning. The emergence of these keywords suggests scholarly interest in understanding educational methods of developing sustainable entrepreneurship in higher education.

\section{Discussion}

This study aspired to use science mapping to analyze the knowledge base of sustainable entrepreneurship. The author conducted a bibliographic analysis of 712 Scopus-indexed documents published between 1996 and 2019. The following section discusses limitations of the review and suggests the interpretation of the findings.

\subsection{Limitations}

First, although the systematic and quantitative approach of science mapping can identify the structure of the knowledge corpus, it cannot replace other review methods (e.g., meta-analysis and qualitative review of literature). Since science mapping mainly analyzes metadata of the documents in the review database, it should be complemented with review methods that examine substantive 
findings of the documents. Hence, this study aim to be an initial step towards a more comprehensive review of the sustainable entrepreneurship literature.

Second, since sustainable entrepreneurship knowledge is in its nascent stage, the conceptual definitions and boundaries of this construct have yet to be established. The unclear boundary of the sustainable entrepreneurship construct resulted in challenges in the selection of documents for review. Moreover, there are earlier constructs put forward by scholars focusing on different aspects of entrepreneurship and sustainability such as ecopreneurship [93,94], environmental entrepreneurship [95], green entrepreneurship [20], social entrepreneurship [88]. The author addressed the limitations of the construct fluidity by adopting a broad perspective on sustainable entrepreneurship that included these related constructs (e.g., ecopreneurship, environmental entrepreneurship, and social entrepreneurship) as the sub-themes of sustainable entrepreneurship. Thus, during the search phase, the author included all these keywords in the review database.

The final limitation lies in the use of Scopus-indexed documents. Despite its wide coverage of documents, it may not cover all existing sustainable entrepreneurship documents. In other words, the literature of the sustainable entrepreneurship field may be larger than the Scopus-indexed documents included in this review. This limitation was partly addressed by conducting the co-citation analysis of all documents listed in the reference section of the documents of this review database. This method enabled the identification of related and influential documents that were not included in the Scopus-indexed review database.

\subsection{Interpretation and Implications of the Findings}

This study found that the size of knowledge base on sustainable entrepreneurship is modest. The pioneering SE documents began to appear in the mid-1990s, with significant growth over the past decade. Analysis of the geographic origins of SE scholarship found that scholars all over the world have been interested in examining how entrepreneurial processes can lead to sustainable business and societies. Nonetheless, SE scholarship identified a concentration of publications authored in Western, developed societies.

This broad trend was reinforced by citation and co-citation analyses that identified key sustainable entrepreneurship documents and authors (i.e., see Tables 2-4). Leading authors were based in the USA (Austin, Stevenson, Wei-Skillern, Zahra, Neubaum, Shulman, Dean, Daneke, Isaak, Lenox, McCullen, Venkataraman, Pacheco, and York), Canada (Hall, Gedajlovic, Peredo, Mclean, Winn), Spain (Mair, Marti), Germany (Schaltegger, Wagner, Kuckertz, Patzelt), UK (Parrish, Gibbs), Austria (Hansen), Australia (Schaper), Denmark (Hockerts), and Switzerland (Wustenhagen).

These data suggest that research on sustainable entrepreneurship from developing societies should be encouraged. This would lead to a more balanced picture of sustainable entrepreneurship practices and effects across the world. This issue is deemed important due to the fact that management processes are influenced by the institutional and cultural context in which they are practiced. Thus, researchers from developing societies could highlight how social, institutional, and cultural contexts shape entrepreneurial processes and sustainability outcomes.

Document quality of this SE scholarship was inferred from the rank and status (i.e., Scopus quartile) of the predominant journals in this field. The review found that 11 of the 20 most highly cited documents in the review database were published in Scopus Q1 journals and two in Scopus Q2 journals. Moreover, SE documents were published in leading entrepreneurship journals such as Entrepreneurship Theory and Practice and Journal of Business Venturing [7,17,24,47,48]. This suggests that the issue of sustainable entrepreneurship has increasingly gained traction within the broader field of entrepreneurship research. At the same time, however, the level of citation impact of these documents is moderate: the number of citations of the top 20 documents ranged from 134 to 1067 (see Table 3). This moderate level of citations may be due partly to the recency of this literature.

When looking at the conceptual structure of the sustainable entrepreneurship literature, author co-citation analysis revealed four Schools of thought comprising the sustainable entrepreneurship 
knowledge base (see Figure 5). Among these, three Schools (i.e., Sustainable Entrepreneurship, Social Entrepreneurship, and Sustainability Innovation) directly examine sustainable entrepreneurship topics. The fourth School represents scholars working on Entrepreneurship and Strategy. This empirically derived picture suggests the emergence of an interdisciplinary knowledge base on sustainable entrepreneurship.

The study used the co-word analysis to identify four clusters of sustainable entrepreneurship topics on which SE scholars have focused. When comparing these topics derived from co-word analysis with the sustainable entrepreneurship conceptual model (see Figure 1), it is found that the foci of scholars tend to cover all five parts of the model (i.e., people, capital, opportunity, context, and sustainable value proposition). For instance, the first topical theme of the keyword analysis features 'sustainable entrepreneurship.' The keywords comprising the first theme cover topics such as sustainable entrepreneurs, ecopreneur, business, business model, innovation, CSR, triple bottom line, ethics, corporate sustainability, and sustainable business. Recent documents examined the role of sustainable entrepreneurs and their sustainable business models in various sectors $[58,82,83]$.

The second topical theme, social entrepreneurship, covers sub-topics such as social enterprise, cooperation, stakeholders, social capital, social impact, social change, and rural area. Recent documents related to these topics studied issues such as social innovation, rural and community development, women entrepreneurs, and microfinance $[88,90,96,97]$. The third topical theme, however, focuses on managing for environmental sustainability $[82,90,91]$. Salient keywords included economic development, environmental management, eco-innovation, technology transfer, renewable energy, climate change, agriculture, tourism, developing countries, energy efficiency, environmental sustainability, economic and social effects. The fourth topical theme, entrepreneurship education, encompasses keywords such as social enterprise, cooperation, stakeholders, social capital, social impact, social change, and rural area. Recent research related to these topics has explored how higher education can create and nurture sustainable entrepreneurship competencies [92].

Although this bibliographic review did not examine in-depth findings of documents in the database, limited insights and implications for future research did emerge from the analysis. First, even though a decade has passed, the definition and conceptual boundaries of sustainable entrepreneurship are still not settled [10]. Apart from the sustainable entrepreneurship construct, scholars have suggested concepts such as responsible entrepreneurship $[8,9]$ and purpose-driven entrepreneurship [14] as umbrella terms for all strands of entrepreneurial activities that go beyond economic profit. Therefore, the author suggests that achieving greater consensus around a clear conceptual definition is a prerequisite for advancing this field. For example, valid measures of the construct cannot be formulated until we understand its conceptual strands and boundaries.

Second, sustainable entrepreneurship scholars have suggested that future research should put greater emphasis on the role of values and ethics of sustainable entrepreneurs $[19,93,94]$. Values drive behaviors and decision-making, as well as the goals to which entrepreneurs aspire. Sustainable entrepreneurs inevitably face ethical dilemmas in balancing economic, social, and environmental goals and managing tradeoffs between short-term and long-term goals $[8,98]$. However, to date, the values that drive entrepreneurs have yet to be featured as a major node in the topical clusters that comprise this field (see Figure 6).

Third, other potential avenues of sustainable entrepreneurship research lie in the role of contextual factors (see Figure 1). Entrepreneurs are embedded in national and local communities that shape the values not only of entrepreneurs but also customers and government agencies $[3,12,98]$. Social, cultural, and institutional contexts in each society would, therefore, support or impede sustainability initiatives of entrepreneurs to different degrees and in different ways [19,82,96,99-101]. What are the practices of sustainable entrepreneurship in different societies, and how do they change over time [13]? How do contextual factors enable and/or constrain sustainable entrepreneurial endeavors? This focus on context should take note of earlier comments encouraging research on sustainable entrepreneurship in developing societies where attitudes towards sustainability may differ and where resource constraints shape attitudes towards the tradeoffs between profitability and sustainability. This line of research 
would highlight the role of context as well as complement the views of the current research, mostly published by scholars from Western societies.

Finally, this review noted that influential documents (see Table 3) on sustainable entrepreneurship are dominated by conceptual papers and qualitative case studies $[11,90]$. Despite the importance of this type of scholarship for laying the foundation of the knowledge base, future research should also include more large-scale quantitative studies that test the theoretical relationships between factors that shape sustainable entrepreneurship (e.g., value, context), entrepreneurial practices, and sustainable outcomes of the firm [13]. Scholars interested in sustainable entrepreneurship are also urged to adopt a configuration and complexity approach $[8,14,98]$ that can account for a more complex, holistic, and processual view of sustainable entrepreneurship [86,102].

\section{Conclusions}

This systematic review of research employed science mapping of the knowledge base on sustainable entrepreneurship as a means of supplementing prior qualitative reviews of this research [8-14]. It is hoped that the findings of this review will both stimulate and guide entrepreneurship scholars towards the field of sustainability and provide a baseline for the future development of this line of inquiry.

Funding: This research and the APC were funded by Thailand Sustainable Development Foundation, Bangkok, Thailand (grant number 008/2561).

Acknowledgments: The author would like to thank Philip Hallinger for his guidance, support and encouragement.

Conflicts of Interest: There were no conflicts of interest.

\section{References}

1. Schumpeter, J.A. The Theory of Economic Development; Harvard University Press: Cambridge, MA, USA, 1934.

2. Hébert, R.F.; Link, A.N. In search of the meaning of entrepreneurship. Small Bus. Econ. 1989, 1, 39-49. [CrossRef]

3. Shane, S.; Venkataraman, S. The promise of entrepreneurship as a field of research. Acad. Manage. Rev. 2000, 25, 217-226. [CrossRef]

4. Venkataraman, S. The Distinctive Domain of Entrepreneurship Research; Social Science Research Network: Rochester, NY, USA, 1997.

5. Keskin, D.; Diehl, J.C.; Molenaar, N. Innovation process of new ventures driven by sustainability. J. Clean. Prod. 2013, 45, 50-60. [CrossRef]

6. Elkington, J. Cannibals with Forks: The Triple Bottom Line of 21st Century Business; Capstone: Mankato, MN, USA, 1997; ISBN 978-1-900961-27-1.

7. Cohen, B.; Winn, M.I. Market imperfections, opportunity and sustainable entrepreneurship. J. Bus. Ventur. 2007, 22, 29-49. [CrossRef]

8. Vallaster, C.; Kraus, S.; Kailer, N.; Baldwin, B. Responsible entrepreneurship: Outlining the contingencies. Int. J. Entrep. Behav. Res. 2019, 25, 538-553. [CrossRef]

9. Tiba, S.; van Rijnsoever, F.J.; Hekkert, M.P. Firms with benefits: A systematic review of responsible entrepreneurship and corporate social responsibility literature. Corp. Soc. Responsib. Environ. Manag. 2019, 26, 265-284. [CrossRef]

10. Gast, J.; Gundolf, K.; Cesinger, B. Doing business in a green way: A systematic review of the ecological sustainability entrepreneurship literature and future research directions. J. Clean. Prod. 2017, 147, 44-56. [CrossRef]

11. Fellnhofer, K.; Bouncken, R.B.; Kraus, S. The Current state of research on sustainable entrepreneurship. Int. J. Bus. Res. 2014, 14, 163-172. [CrossRef]

12. Levinsohn, D. Disembedded and Beheaded?-A critical review of the emerging field of sustainability entrepreneurship. Int. J. Entrep. Small Bus. 2013, 19, 190-211. [CrossRef]

13. Sarango-Lalangui, P.; Santos, J.L.S.; Hormiga, E. The development of sustainable entrepreneurship research field. Sustainability 2018, 10, 2005. [CrossRef] 
14. Muñoz, P.; Cohen, B. Sustainable entrepreneurship research: Taking stock and looking ahead. Bus. Strategy Environ. 2018, 27, 300-322. [CrossRef]

15. Zupic, I.; Čater, T. Bibliometric methods in management and organization. Organ. Res. Methods 2015, 18, 429-472. [CrossRef]

16. van Eck, N.J.; Waltman, L. Citation-based clustering of publications using CitNetExplorer and VOSviewer. Scientometrics 2017, 111, 1053-1070. [CrossRef] [PubMed]

17. Austin, J.; Stevenson, H.; Wei-Skillern, J. Social and commercial entrepreneurship: Same, different, or both? Entrep. Theory Pract. 2006, 30, 1-22. [CrossRef]

18. Sahlman, W.A. Some thoughts on business plans. In The Entrepreneurial Venture; Sahlman, W.A., Stevenson, H.H., Roberts, M.J., Bhide, A.V., Eds.; Harvard Business School Press: Boston, MA, USA, 1996; pp. 138-176.

19. Kraus, S.; Burtscher, J.; Vallaster, C.; Angerer, M. Sustainable entrepreneurship orientation: A reflection on status-quo research on factors facilitating responsible managerial practices. Sustainability 2018, 10, 444. [CrossRef]

20. Berle, G. The Green Entrepreneur: Business Opportunities That Can Save the Earth Make You Money; Liberty Hall Press: New York, NY, USA, 1993.

21. Melay, I.; Kraus, S. Green entrepreneurship: Definitions of related concepts. Int. J. Strateg. Manag. 2012, 12, $1-12$.

22. Patagonia Mission Statement-Our Reason For Being. Available online: https://www.patagonia.com/ company-info.html (accessed on 6 May 2019).

23. Mair, J.; Martí, I. Social entrepreneurship research: A source of explanation, prediction, and delight. J. World Bus. 2006, 41, 36-44. [CrossRef]

24. Zahra, S.A.; Gedajlovic, E.; Neubaum, D.O.; Shulman, J.M. A typology of social entrepreneurs: Motives, search processes and ethical challenges. J. Bus. Ventur. 2009, 24, 519-532. [CrossRef]

25. Seelos, C.; Mair, J. Social entrepreneurship: Creating new business models to serve the poor. Bus. Horiz. 2005, 48, 241-246. [CrossRef]

26. Schaltegger, S.; Wagner, M. Sustainable entrepreneurship and sustainability innovation: Categories and interactions. Bus. Strategy Environ. 2011, 20, 222-237. [CrossRef]

27. Stecker, M.J. Awash in a sea of confusion: Benefit corporations, social enterprise, and the fear of “greenwashing". J. Econ. Issues 2016, 50, 373-381. [CrossRef]

28. Tarnanidis, T.; Papathanasiou, J.; Subeniotis, D. How far the TBL concept of sustainable entrepreneurship extends beyond the various sustainability regulations: Can Greek food manufacturing enterprises sustain their hybrid nature over time? J. Bus. Ethics 2019, 154, 829-846. [CrossRef]

29. Pohludka, M.; Stverkova, H.; Ślusarczyk, B. Implementation and unification of the ERP system in a global company as a strategic decision for sustainable entrepreneurship. Sustainability 2018, 10, 2916. [CrossRef]

30. Yan, X.; Gu, D.; Liang, C.; Zhao, S.; Lu, W. Fostering sustainable entrepreneurs: Evidence from China college students' "Internet Plus" innovation and entrepreneurship competition (CSIPC). Sustainability 2018, 10, 3335. [CrossRef]

31. Fichter, K.; Tiemann, I. Factors influencing university support for sustainable entrepreneurship: Insights from explorative case studies. J. Clean. Prod. 2018, 175, 512-524. [CrossRef]

32. Visualizing a discipline: An author co-citation analysis of information science. Available online: https://onlinelibrary.wiley.com/doi/abs/10.1002/\%28SICI\%291097-4571\%2819980401\%2949\%3A4\% 3C327\%3A\%3AAID-ASI4\%3E3.0.CO\%3B2-4 (accessed on 6 May 2019).

33. Short, J.C.; Moss, T.W.; Lumpkin, G.T. Research in social entrepreneurship: Past contributions and future opportunities. Strateg. Entrep. J. 2009, 3, 161-194. [CrossRef]

34. Rey-Martí, A.; Ribeiro-Soriano, D.; Palacios-Marqués, D. A bibliometric analysis of social entrepreneurship. J. Bus. Res. 2016, 69, 1651-1655. [CrossRef]

35. Pato, M.L.; Teixeira, A.A.C. Twenty years of rural entrepreneurship: A bibliometric survey. Sociol. Rural. 2016, 56, 3-28. [CrossRef]

36. Bettinelli, C.; Sciascia, S.; Randerson, K.; Fayolle, A. Researching entrepreneurship in family firms. J. Small Bus. Manag. 2017, 55, 506-529. [CrossRef]

37. Moreira, J.; Marques, C.S.; Braga, A.; Ratten, V. A systematic review of women's entrepreneurship and internationalization literature. Thunderbird Int. Bus. Rev. 2019, 61, 635-648. [CrossRef] 
38. Rodríguez-Ruiz, F.; Almodóvar, P.; Nguyen, Q.T.K. Intellectual structure of international new venture research: A bibliometric analysis and suggestions for a future research agenda. Multinatl. Bus. Rev. 2019. [CrossRef]

39. Mongeon, P.; Paul-Hus, A. The journal coverage of Web of Science and Scopus: A comparative analysis. Scientometrics 2016, 106, 213-228. [CrossRef]

40. Falagas, M.E.; Pitsouni, E.I.; Malietzis, G.A.; Pappas, G. Comparison of PubMed, Scopus, Web of Science, and Google Scholar: Strengths and weaknesses. FASEB J. Off. Publ. Fed. Am. Soc. Exp. Biol. 2008, 22, 338-342. [CrossRef] [PubMed]

41. Moher, D. Preferred reporting items for systematic reviews and meta-analyses: The PRISMA statement. Ann. Intern. Med. 2009, 151, 264. [CrossRef]

42. McCain, K.W. Mapping authors in intellectual space: A technical overview. J. Am. Soc. Inf. Sci. 1990, 41, 433-443. [CrossRef]

43. Hallinger, P.; Chatpinyakoop, C. A Bibliometric review of research on higher education for sustainable development, 1998-2018. Sustainability 2019, 11, 2401. [CrossRef]

44. Hallinger, P.; Kovačević, J. A bibliometric review of research on educational administration: Science mapping the literature, 1960 to 2018. Rev. Educ. Res. 2019, 89, 335-369. [CrossRef]

45. Hallinger, P.; Suriyankietkaew, S. Science mapping of the knowledge base on sustainable leadership, 1990-2018. Sustainability 2018, 10, 4846. [CrossRef]

46. Meek, W.R.; Pacheco, D.F.; York, J.G. The impact of social norms on entrepreneurial action: Evidence from the environmental entrepreneurship context. J. Bus. Ventur. 2010, 25, 493-509. [CrossRef]

47. Dean, T.J.; McMullen, J.S. Toward a theory of sustainable entrepreneurship: Reducing environmental degradation through entrepreneurial action. J. Bus. Ventur. 2007, 22, 50-76. [CrossRef]

48. Hockerts, K.; Wüstenhagen, R. Greening Goliaths versus emerging Davids-Theorizing about the role of incumbents and new entrants in sustainable entrepreneurship. J. Bus. Ventur. 2010, 25, 481-492. [CrossRef]

49. Young, W.; Tilley, F. Can businesses move beyond efficiency? The shift toward effectiveness and equity in the corporate sustainability debate. Bus. Strategy Environ. 2006, 15, 402-415. [CrossRef]

50. Pacheco, D.F.; Dean, T.J.; Payne, D.S. Escaping the green prison: Entrepreneurship and the creation of opportunities for sustainable development. J. Bus. Ventur. 2010, 25, 464-480. [CrossRef]

51. Kuckertz, A.; Wagner, M. The influence of sustainability orientation on entrepreneurial intentions-Investigating the role of business experience. J. Bus. Ventur. 2010, 25, 524-539. [CrossRef]

52. Larson, A.L. Sustainable innovation through an entrepreneurship lens. Bus. Strategy Environ. 2000, 9, 304-317. [CrossRef]

53. Marsden, T.; Smith, E. Ecological entrepreneurship: Sustainable development in local communities through quality food production and local branding. Geoforum 2005, 36, 440-451. [CrossRef]

54. Parrish, B.D. Sustainability-driven entrepreneurship: Principles of organization design. J. Bus. Ventur. 2010, 25, 510-523. [CrossRef]

55. Peredo, A.M.; McLean, M. Social entrepreneurship: A critical review of the concept. J. World Bus. 2006, 41, 56-65. [CrossRef]

56. Hall, J.K.; Daneke, G.A.; Lenox, M.J. Sustainable development and entrepreneurship: Past contributions and future directions. J. Bus. Ventur. 2010, 25, 439-448. [CrossRef]

57. Ateljevic, I.; Doorne, S. 'Staying within the fence': Lifestyle entrepreneurship in tourism? J. Sustain. Tour. 2000, 8, 378-392. [CrossRef]

58. Klewitz, J.; Hansen, E.G. Sustainability-oriented innovation of SMEs: A systematic review. J. Clean. Prod. 2014, 65, 57-75. [CrossRef]

59. York, J.G.; Venkataraman, S. The entrepreneur-environment nexus: Uncertainty, innovation, and allocation. J. Bus. Ventur. 2010, 25, 449-463. [CrossRef]

60. Barney, J.B. Firm resources and sustained competitive advantage. J. Manag. 1991, 17, 99-120. [CrossRef]

61. Eisenhardt, K.M. Building theories from case study research. Acad. Manage. Rev. 1989, 14, 532-550. [CrossRef]

62. Eisenhardt, K.M.; Graebner, M.E. Theory building from cases: Opportunities and challenges. Acad. Manage. J. 2007, 50, 25-32. [CrossRef]

63. Cohen, B.; Smith, B.; Mitchell, R. Toward a sustainable conceptualization of dependent variables in entrepreneurship research. Bus. Strategy Environ. 2008, 17, 107-119. [CrossRef] 
64. Patzelt, H.; Shepherd, D.A. Recognizing opportunities for sustainable development. Entrep. Theory Pract. 2011, 35, 631-652. [CrossRef]

65. White, H.D.; McCain, K.W. Visualizing a discipline: An author co-citation analysis of information science, 1972-1995. J. Am. Soc. Inf. Sci. 1998, 49, 327-355.

66. Small, H. Visualizing science by citation mapping. J. Am. Soc. Inf. Sci. 1999, 50, 799-813. [CrossRef]

67. Kuratko, D.F. The emergence of entrepreneurship education: Development, trends, and challenges. Entrep. Theory Pract. 2005, 29, 577-597. [CrossRef]

68. Covin, J.G. Strategic management of small firms in hostile and benign environments. Strateg. Manag. J. 1989, 10, 75-87. [CrossRef]

69. Wiklund, J.; Davidsson, P.; Audretsch, D.B.; Karlsson, C. The future of entrepreneurship research. Entrep. Theory Pract. 2011, 35, 1-9. [CrossRef]

70. Lumpkin, G.T.; Dess, G.G. Clarifying the entrepreneurial orientation construct and linking it to performance. Acad. Manage. Rev. 1996, 21, 135-172. [CrossRef]

71. Etzkowitz, H.; Leydesdorff, L. The dynamics of innovation: From national systems and "mode 2" to a triple helix of university-industry-government relations. Res. Policy. 2000, 29, 109-123. [CrossRef]

72. Audretsch, D.B. From the entrepreneurial university to the university for the entrepreneurial society. J. Technol. Transf. 2014, 39, 313-321. [CrossRef]

73. Porter, M.E.; Kramer, M.R. Creating shared value. Harv. Bus. Rev. 2011, 89, 62-77.

74. Freeman, R.E. Strategic Management: A Stakeholder Approach, 1st ed.; Harpercollins College Div: Boston, MA, USA, 1984; ISBN 978-0-273-01913-8.

75. Carroll, A.B. A three-dimensional conceptual model of corporate social performance. Acad. Manage. Rev. 1979, 4, 497-505. [CrossRef]

76. McWilliams, A.; Siegel, D. Corporate social responsibility: A theory of the firm perspective. Acad. Manage. Rev. 2001, 26, 117-127. [CrossRef]

77. Yin, R.K. Case Study Research: Design and Methods, 4th ed.; Sage Publications: Los Angeles, CA, USA, 2009; ISBN 978-1-4129-6099-1.

78. McMullen, J.S.; Shepherd, D.A. Entrepreneurial action and the role of uncertainty in the theory of the entrepreneur. Acad. Manage. Rev. 2006, 31, 132-152. [CrossRef]

79. Dees, J.G. Taking social entrepreneurship seriously. Society 2007, 44, 24-31. [CrossRef]

80. Hart, S.L.; Milstein, M.B. Creating sustainable value. Acad. Manag. Exec. 2003, 17, 56-67. [CrossRef]

81. Dyllick, T.; Hockerts, K. Beyond the business case for corporate sustainability. Bus. Strategy Environ. 2002, 11, 130-141. [CrossRef]

82. Nosratabadi, S.; Mosavi, A.; Shamshirband, S.; Kazimieras Zavadskas, E.; Rakotonirainy, A.; Chau, K.W. Sustainable business models: A review. Sustainability 2019, 11, 1663. [CrossRef]

83. Barth, H.; Ulvenblad, P.-O.; Ulvenblad, P. Towards a conceptual framework of sustainable business model innovation in the agri-food sector: A systematic literature review. Sustainability 2017, 9, 1620. [CrossRef]

84. Stål, H.I. Business models based on strongly sustainable entrepreneurship: Insights from a systematic literature review. In Strongly Sustainable Societies: Organising Human Activities on a Hot and Full Earth; Routledge: London, UK, 2018; pp. 153-171.

85. Muñoz, P.; Cacciotti, G.; Cohen, B. The double-edged sword of purpose-driven behavior in sustainable venturing. J. Bus. Ventur. 2018, 33, 149-178. [CrossRef]

86. Kraus, S.; Burtscher, J.; Niemand, T.; Roig-Tierno, N.; Syrjä, P. Configurational paths to social performance in SMEs: The interplay of innovation, sustainability, resources and achievement motivation. Sustainability 2017, 9, 1828. [CrossRef]

87. Blowfield, M.; Dolan, C. Fairtrade facts and fancies: What Kenyan fairtrade tea tells us about business' role as development agent. J. Bus. Ethics. 2010, 93, 143-162. [CrossRef]

88. Bansal, S.; Garg, I.; Sharma, G.D. Social entrepreneurship as a path for social change and driver of sustainable development: A systematic review and research agenda. Sustainability 2019, 11, 1091. [CrossRef]

89. Singh, A.; Majumdar, S.; Saini, G.K. Corporate social responsibility and social entrepreneurship: An Indian context. J. Entrep. Innov. Emerg. Econ. 2017, 3, 71-76. [CrossRef]

90. Eichler, G.M.; Schwarz, E.J. What sustainable development goals do social innovations address? A systematic review and content analysis of social innovation literature. Sustainability 2019, 11, 522. [CrossRef] 
91. Christensen, L.J.; Thomas, J.; Thomas, J. Procter \& Gamble's PuR Water Purifier: The Hunt for a Sustainable Business Model 1, 2, 3, 4. Available online: https://www.taylorfrancis.com/ (accessed on 31 March 2019).

92. Lans, T.; Blok, V.; Wesselink, R. Learning apart and together: Towards an integrated competence framework for sustainable entrepreneurship in higher education. J. Clean. Prod. 2014, 62, 37-47. [CrossRef]

93. Isaak, R. Green logic: Ecopreneurship, theory and ethics; Greenleaf: Sheffield, UK, 1998; ISBN 978-1-874719-12-0.

94. Vallaster, C.; Kraus, S.; Lindahl, J.M.M.; Nielsen, A. Ethics and entrepreneurship: A bibliometric study and literature review. J. Bus. Res. 2019, 99, 226-237. [CrossRef]

95. Lenox, M.; York, J.G. Environmental entrepreneurship. Oxf. Handb. Bus. Nat. Environ. 2011. [CrossRef]

96. Lubberink, R.; Blok, V.; Van Ophem, J.; Omta, O. Lessons for responsible innovation in the business context: A systematic literature review of responsible, social and sustainable innovation practices. Sustainability 2017, 9, 721. [CrossRef]

97. Kraus, S.; Filser, M.; O’Dwyer, M.; Shaw, E. Social entrepreneurship: An exploratory citation analysis. Rev. Manag. Sci. 2014, 8, 275-292. [CrossRef]

98. Schaefer, K.; Corner, P.D.; Kearins, K. Social, environmental and sustainable entrepreneurship research: What is needed for sustainability-as-flourishing? Organ. Environ. 2015, 28, 394-413. [CrossRef]

99. Macke, J.; Sarate, J.A.R.; Domeneghini, J.; Silva, K.A.D. Where do we go from now? Research framework for social entrepreneurship. J. Clean. Prod. 2018, 183, 677-685. [CrossRef]

100. Goyal, S.; Sergi, B.S. Social entrepreneurship and sustainability-Understanding the context and key characteristics. J. Secur. Sustain. Issues 2015, 4, 269-278. [CrossRef]

101. Thornton, P.H. The sociology of entrepreneurship. Annu. Rev. Sociol. 1999, 25, 19-46. [CrossRef]

102. Shane, S. Reflections on the 2010 AMR decade award: Delivering on the promise of entrepreneurship as a field of research. Acad. Manage. Rev. 2012, 37, 10-20. [CrossRef]

(C) 2019 by the author. Licensee MDPI, Basel, Switzerland. This article is an open access article distributed under the terms and conditions of the Creative Commons Attribution (CC BY) license (http://creativecommons.org/licenses/by/4.0/). 